\title{
First isolation of Cytophaga psychrophila from a systemic disease in eel and cyprinids
}

\author{
Jens Lehmann ${ }^{1}$, Dieter Mock ${ }^{1}$, Franz-Josef Stürenberg ${ }^{1}$, Jean-François Bernardet $^{2}{ }^{2 *}$ \\ ${ }^{1}$ Landesanstalt für Fischerei Nordrhein-Westfalen, W-5942 Kirchhunden-Albaum, Germany \\ ${ }^{2}$ Laboratoire de Virologie-Immunologie Moléculaires, Centre de Recherches INRA, F-78352 Jouy-en-Josas Cedex, France
}

\begin{abstract}
Four Cytophaga psychrophila-like strains were isolated from one eel and 3 species of cyprinids with skin lesions and signs of acute septicaemia in Nordrhein-Westfalen (Germany). The strains proved identical in their phenotypic characteristics to each other and to 3 typical strains of $C$. psychrophila, one of which was the type strain. The identification of the new isolates as C. psychrophila was confirmed by rapid slide agglutination tests using a specific rabbit anti- $C$. psychrophila serum. This is the first report of C. psychrophila being isolated from non-salmonid fishes. This pathogen, which has provoked heavy losses in rainbow trout hatcheries in France and Germany since 1984-1985, may also have the potential to become a problem for non-salmonids. As with most other bacteria pathogenic for fish, C. psychrophila shows a lack of strict host specificity.
\end{abstract}

Cytophaga psychrophila (= Flexibacter psychrophilus) was originally isolated from diseased coho salmon Oncorhynchus kisutchin Washington State, USA, in 1948 (Borg 1960). This bacterium is the causative agent of a systemic infection known as 'cold-water disease', 'lowtemperature disease' or 'peduncle disease'

Until 1988, the condition had only been reported in the northern states of the USA and in Canada. However, the same bacterium has been recognized since 1988 in western and central Europe as the causative agent of a serious systemic disease in farmed rainbow trout Oncorhynchus mykiss (Bernardet et al. 1988, Lehmann et al. 1988).

Until recently, the condition was believed to be restricted to salmonids (Oncorhynchus spp., Salvelinus spp., and Salmo spp.). However, in November 1989, examinations of a wild diseased eel Anguilla anguilla from the river Weser in the state of Nordrhein-Westfalen, Germany, revealed the existence of a Cytophaga psychrophila-like infection (Lehmann et al. 1990). The eel had a body length of $50 \mathrm{~cm}$, was very lethargic, and showed the following gross lesions: haemorrhages in the unpaired fins, dorsal muscular system, peritoneum,

\footnotetext{
- Author for correspondence
}

(C) Inter-Research/Printed in Germany and swim-bladder wall; inflammation of the intestine; and a blister in the region of the anus. The river Weser is highly polluted with $\mathrm{NaCl}$ and $\mathrm{KCl}$ from salt factories in the east of Germany (average ion concentrations in 1989 at the site where the eel was collected were $\mathrm{Na}=$ $860.9 \mathrm{mg} \mathrm{l}^{-1}, \mathrm{~K}=77.2 \mathrm{mg} \mathrm{l}^{-1}$, and $\mathrm{Cl}=1661.4 \mathrm{mg} \mathrm{l}^{-1}$ ). Bacterial infections with motile Aeromonas and with Vibrio anguillarum are common among eels in this part of the river. The water temperature in November 1989 was about 8 to $10^{\circ} \mathrm{C}$ but the rate of mortality among eels during this period was unknown. Virological and parasitic examinations were negative and no bacteria could be isolated on Tryptone Soya agar at $20^{\circ} \mathrm{C}$. However, on Anacker and Ordal agar (AOA) (Anacker \& Ordal 1955), a C. psychrophila-like organism (i.e. a gliding Gram-negative rod producing bright yellow, non-adherent colonies on AOA) was isolated in pure culture from liver, kidney, and spleen. In imprints of spleen tissue, the bacteria appeared as rather long rods, and occurred especially in granulocytes and leucocytes (Fig. 1).

Other Cytophaga psychrophila-like strains were subsequently isolated by the same procedure: in February 1990 from diseased carp Cyprinus carpio, in March 1990 from diseased tench Tinca tinca, and in April 1990 from diseased crucian carp Carassius carassius. All of the fishes were caught in different ponds and artificial lakes in Nordrhein-Westfalen where mixed species culture is common. The water temperature was 8 to $12^{\circ} \mathrm{C}$ at the time of collection for all 3 species of fish. There was no indication of water pollution at any of the sites examined. Carp and tench aged 2 to 3 yr had been introduced into the ponds a few weeks earlier, and at the time of collection the mortality among these fish had reached 40 to $50 \%$. Five fish of each species, exhibiting gross lesions similar to those previously described for the eel, were sampled. The C. psychrophila-like organism was isolated in pure culture from the spleen and/or 


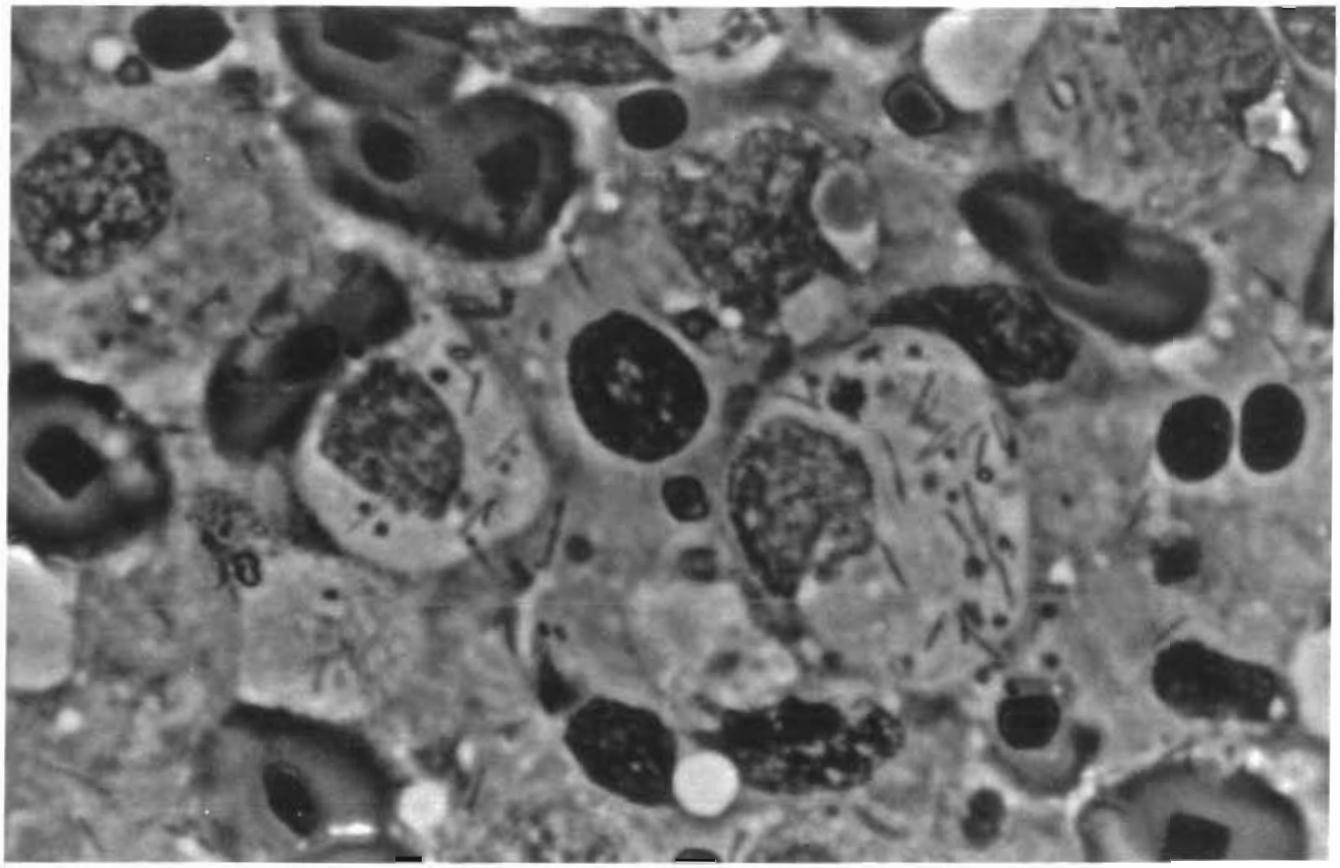

Fig. 1. Anguilla anguilla infected with Cytophaga paychrophila. Imprint of spleen tissue. Note the numerous bacteria inside the leucocytes. Pappenheim, phasecontrast microscopy, $1000 \times$ the liver of all fish. This bacterium was also isolated from crucian carp suffering a mixed septicemic infection with Aeromonas hydrophila.

Four strains we isolated lone from the eel, one from a carp, and 2 from tench) were compared to the type strain of Cytophaga psychrophila (NCIMB $1947^{\mathrm{T}}$, National Collection of Industrial and Marine Bacteria, Aberdeen, Scotland) and to 2 C. psychrophila strains isolated from salmonids in France (ATCC 49510 and 49511, American Type Culture Collection, Rockville, USA). The morphological and biochemical tests used have been described previously (Bernardet \& Grimont 1989, Bernardet \& Kerouault 1989, Bernardet et al. 1990). The results of these tests indicated that all of the new isolates conformed to the description of the bacterial species C. psychrophila (Bernardet \& Grimont 1989) (Table 1). The following characteristics are particularly significant: colonies on AOA were smooth, glossy, bright yellow, and did not adhere to the agar; as frequently observed for C. psychrophila, the 4 isolates produced both circular colonies with regular edges and other colonies exhibiting narrow and uneven spreading margins on the same agar plate (Fig. 2); cells were Gram-negative rods 1 to $5 \mu \mathrm{m}$ long and 0.3 to $0.5 \mu \mathrm{m}$ wide in $48 \mathrm{~h}$ liquid cultures; in hanging drop preparations, the gliding movement of the bacterial cells in contact with the cover slip (typical of most bacterial species belonging to the order Cytophagales) was usually slow and difficult to observe; gliding was more readily observed directly on agar, at the margin of the spreading zone, by phase contrast microscopy (Henrichsen 1972); the pigments were nondiffusible and belonged to the flexirubin type as demonstrated by a positive result in the $\mathrm{KOH}$ test (Reichenbach et al. 1980); colonies did not absorb Congo red and thus did not produce an extracellular galactosamine glycan (McCurdy 1969); catalase and cytochrome oxidase were produced and most clearly shown with young colonies ( 2 to $4 \mathrm{~d}$ ); all of the strains tested grew well at $5^{\circ} \mathrm{C}$ but did not grow above $26^{\circ} \mathrm{C}$; there was no growth on Tryptone Soya (TS) agar or in TS broth. The enzyme production patterns as tested in API ZYM galleries (API System, La Balme-les-Grottes, France) were identical to the pattern previously published in the description of the species C. psychrophila (Bernardet \& Grimont 1989). The negative result found for all of the enzymes involved in carbohydrate metabolism (Nos. 13 to 20 in the galleries) was shared in common with Flexibacter columnaris and F. maritimus. This feature clearly distinguishes these 3 fish-pathogens from the saprophytic or opportunistic Cytophagales commonly isolated from the external lesions of fish. The latter organisms are usually related to Cytophaga aquatilis and C. johnsonae (Bernardet unpubl.).

A specific antiserum was produced by immunizing a rabbit with formalin-killed cells of the Cytophaga psychrophila type strain (NCIMB $1947^{\mathrm{T}}$ ) injected intradermally (A. Paraf pers. comm.). The agglutinating titer of the antiserum was 1/128. Bacterial cells of all the strains studied were cultivated on AOA plates, suspended in saline, and heated for 10 to $15 \mathrm{~min}$ at $50^{\circ} \mathrm{C}$ to prevent autoagglutination (Holt 1987). Rapid slide agglutination tests showed that the 4 strains isolated from eel and cyprinids in Germany, as well as the 2 
French strains isolated from salmonids, reacted strongly with the specific anti-NCIMB $1947^{\mathrm{T}}$ serum, whereas there was no agglutination either with the serum from a non-immunized rabbit or with saline only. The antiserum did not agglutinate the cells of Flexibacter columnaris NCIMB $2248^{\top}, F$. maritimus NCIMB $2154^{\top}$, or 4 strains related to $C$. aquatilis and $C$. johnsonae that we had isolated from external lesions of fish.

The phenotypic properties of the Cytophaga psychrophila-like strains isolated from the diseased eel and the cyprinids in Germany are therefore identical to those of the type strain of the species and to the $C$. psychrophila strains previously isolated from salmonids. The serological similarity to the type strain of the species is onc more argument for their identitication as $C$. psychrophila. These studies are the first to show that $C$. psychrophila can infect non-salmonid fishes. Experimental studies are needed to confirm the pathogenicity of the 4 isolates because several other factors may have contributed to the observed disease. These include the pollution of the river Weser, the recent introduction of (and the consequent stress to) the carp and tench in the ponds, and the presence of other bacterial species such as Aeromonas and Vibrio spp. If these strains are found to be pathogenic to non-salmonid fishes (e.g. Anguillidae and Cyprinidae), it may indicate that C. psychrophila will become more important as a pathogen in Europe. The severity of the problem for salmonids has already been observed in several rainbow trout hatcheries in Nordrhein-Westfalen and in western and southwestern France. Furthermore, the spread of C. psychrophila by non-salmonid fishes with apparent or inapparent infections could be an important factor in the epizootiology of cold-water disease among salmonid populations in Europe. Finally, the present findings with Cytophaga psychrophila provide another example of the lack of host specificity among bacteria pathogenic for fish.

Acknowledgement. We are most grateful to Ronald Hedrick who kindly reviewed the manuscript.

\section{LITERATURE CITED}

Anacker, R. L., Ordal, E. J. (1955). Study of a bacteriophage infecting the myxobacterium Chondrococcus columnaris. J. Bacteriol. 70: 738-741

Bernardet, J. F, Baudin-Laurencin, F., Tixerand, G. (1988). First identification of 'Cytophaga psychrophila' in France. Bull. Eur. Ass. Fish Pathol 8: 104-105

Responsible Subject Editor $T$ Evelyn, Nanaimo, B. C., Canada
Bernardet, J. F., Kerouault, B. (1989). Phenotypic and genomic studies of Cytophaga psychrophila isolated from diseased rainbow trout (Oncorhynchus mykiss) in France. Appl. environ. Microbiol. 55: 1796-1800

Bernardet, J. F., Grimont, P. A. D. (1989). Deoxyribonucleic acid relatedness and phenotypic characterization of Flexibacter columnaris sp. nov., nom. rev., Flexibacter psychrophilus sp. nom., nom. rev., and Flexibacter maritimus Wakabayashi, Hikida and Masumura, 1986. Int. J. Syst. Bacteriol. 39: 346-354

Bernardet, J. F., Campbell, A. C., Buswell, J. A. (1990). Flexibacter maritimus is the agent of 'black patch necrosis' in Dover sole in Scotland. Dis. aquat. Org. 8: 233-237

Borg, A. F. (1960). Studies on myxobacteria associated with diseases in salmonid fishes. J. Wildl. Dis. 8: 1-85 (Two microcards)

Bullock, G. L. (1972). Studies on selected myxobacteria pathogenic for fishes. US Dept Interior, Fish and Wildlife Service, Bureau of Sport Fisheries and Wildifie; Tecinitical paper no. 60: 4-19

Cowan, S. T., Steel, K. J. (1974). Manual for the identification of medical bacteria, 2nd edn. Cambridge University Press, Cambridge

Henrichsen, J. (1972). Bacterial surface translocation: a survey and classification. Bacteriol. Rev. 36: 478-503

Holt, R. A. (1987). Cytophaga psychrophila, the causative agent of bacterial cold-water disease in salmonid fish. Ph.D. thesis, Oregon State University, Corvallis

Lehmann, J., Mock, D., Stürenberg, F. J. (1988). Zur Ausbreitung der bakteriellen Kaltwasserkrankheit (BKK) in Nordrhein-Westfalen. Fischer und Teichwirt 7: 206-207

Lehmann, J., Mock, D., Stürenberg, F. J. (1990). Kurzinformation zur weiteren Ausbreitung der bakteriellen Kaltwasserkrankheit (BKK) bei Nichtsalmoniden. Fischer und Teichwirt. 1: 9

Le Minor, L., Piechaud, M. (1963). Une méthode rapide de recherche de la protéolyse de la gélatine. Annls Inst. Pasteur, Paris 105: 792-794

Lewin, R. A., Lounsbery, D. M. (1969). Isolation, cultivation and characterization of flexibacteria. J. gen. Microbiol. 58: $145-170$

McCurdy, H. D. (1969). Studies on the taxonomy of the Myxobacterales: I. Record of Canadian isolates and survey of methods. Can. J. Microbiol. 15: 1453-1461

Mourey, A., Kilbertus, G. (1976). Simple media containing stabilized tributyrin for demonstrating lipolytic bacteria in foods and soils. J. appl. Bacteriol. 40: 47-51

Pacha, R. (1968). Characteristics of Cytophaga psychrophila (Borg) isolated during outbreaks of bacterial cold-water disease. Appl. Microbiol. 16: 97-101

Reichenbach, H., Dworkin, M. (1981). The Order Cytophagales (with addenda on the genera Herpetosiphon, Saprospira and Flexithrix). In: Starr et al. (eds.) The prokaryotes, Vol. 1. Springer Verlag, New York, p. 356-379

Reichenbach, H., Kohl, W., Böttger-Vetter, A., Achenbach, H. (1980). Flexinubin-type pigments in Flavobacterium. Arch. Microbıl. 126: 291-293

Sierra, G. (1957). A simple method for the detection of lipolytic activity of microorganisms and some observations on the influence of the contact between cells and fatty substrates. Antonie van Leeuwenhoek 23: 15

Manuscript first received: July 5, 1990

Revised version accepted: March 5, 1991 